\title{
The Influence of Religiosity and Local Philosophy on Nurse Performance: A Case Study of Government Hospital
}

\author{
S Syamsuriansyah* \\ Medical Records and Health Information \\ Politeknik Medica Farma Husada| \\ Mataram, Indonesia \\ sam_bptk@yahoo.com
}

\author{
Jihadil Qudsi \\ Medical Records and Health Information \\ Politeknik Medica Farma Husada \\ Mataram, Indonesia
}

\begin{abstract}
Nurse performance is a part that is always faced by hospital management. Nurse performance does not always increase, sometimes there is an unexpected decrease in the work of nurses. So that the hospital management needs to know what factors can affect the performance of nurses. Several studies that have been conducted by researchers on nurse performance have found several influencing factors. However, only a few have examined it in terms of religiosity and the local philosophy of nurses. The research was conducted in 2 government hospitals on Lombok Island, West Nusa Tenggara, namely the Mataram City General Hospital and the West Nusa Tenggara Public Hospital. Methods of data analysis using Multiple Linear Regression with Partial Least Square (PLS) approach in looking for influential factors and the magnitude of the coefficients. The results obtained are that in Mataram City Hospital, the Local Philosophy factor and the religiosity factor have a significant effect on the Nurse Performance factor with a large influence of 0.545 for local philosophy and $\mathbf{0 . 2 2 9}$ for religiosity. In the West Nusa Tenggara Public Hospital, local philosophical factors do not significantly affect the performance of nurses, and the size of the influence is very small, only 0.083 , while the religiosity factor has a significant effect with a large influence of 0.386 . There is a difference between the results of the influence of local philosophy and religiosity on the performance of nurses at the Mataram City Public Hospital and the West Nusa Tenggara Public Hospital.
\end{abstract}

Keywords-Local Philosophy, Multiple Linear Regression, Nurse Performance, Partial Least Square, Religiosity

\section{INTRODUCTION}

The hospital is considered as one of the health facilities that have an important role in improving the level of public health. The hospital is a health service institution that organizes health services that are very beneficial in providing health services to the community, as stated in Law RI No. 44 of 2009 clause 1 [1]. Therefore, the hospital is required to provide quality services that are highly determined by the human resources in it. Nurses in this case nurses who are an inseparable part of Human Resources for Health, of course, their abilities and competencies must be improved to improve the quality of health services, especially nursing services in hospitals [2].

West Nusa Tenggara is a province in Indonesia located in the western part of the Nusa Tenggara Islands. This province has its capital in Mataram and has 10 Regencies / Cities. Each city and district has regional public hospitals as a place for public health services. The health services of regional public hospitals in NTB Province have progressed quite well in the last three years. This is evidenced by an increase in access to health services in hospitals (outpatient and inpatient visits), but there are still some weakness factors that will hinder the optimization of future health improvement, one of which is the low performance of nurses [3].

Based on the monitoring and evaluation of nurse performance conducted by the West Nusa Tenggara Provincial Health Service in 2018 based on five nursing care directly related to nursing performance, the average nurse performance at the Mataram City General Hospital is $79.4 \%$ in 2016 and $82.7 \%$ in 2017 and the average nurse performance at the West Nusa Tenggara General Hospital is $75.3 \%$ in 2016 and $80.1 \%$ in 2017 [4]. This figure is fairly low because it means there is still a percentage of complaints and dissatisfaction from the public about the performance of nurses at the Mataram City General Hospital and West Nusa Tenggara General Hospital.

Several studies conducted to determine the factors of nurse performance have been carried out. These factors include public service motivation (PSM) [5] [6], and leadership [7][8][9], organizational commitment [10][11]. Discussion about the effect of religion on nurse performance is still lacking. The study of the effect of religiosity on prosocial behavior [2], the effect of religiosity on office employee performance [12], and religiosity affect the surrounding environment in society [13].

With the existence of religiosity, a religious person should always try to do the best and not violate the rules in behaving and behaving in each of his activities, which is under the norms and rules set in his religion [14]. Religiosity is also very important to be owned by an employee, because if an employee has a high level of religiosity, then the motivation of employees to produce good achievements or performance will also be higher [15]. Because a nurse is also an employee in the health sector, so the factor of religiosity should affect the nurse's performance.

The culture value factor is also unique to discuss because Indonesia consists of many tribes and cultures so that with high cultural values in each individual, it can encourage someone with a particular ethnicity/culture to become more competitive and strive for success. This also contributes to improved performance. A nurse who has cultural competence will care for and be sensitive to the cultural needs of patients who receive nursing care. At this time, the cultural 
competence of nurses in Indonesia is still not a concern, the majority of nurses have not been prepared for cultural competency during the education process. The lack of nurse's cultural competence can result in many problems in interacting between patients and nurses [7].

This study aims to help hospitals to determine whether religious factors and local philosophical factors can improve the performance of nurses at hospitals in Lombok Island, West Nusa Tenggara. One of the reasons for taking the hospital on the island of Lombok as an object is because the people of the island of Lombok are people who adhere to a religion, customs, and culture.

\section{METHODS}

This study uses a mixed-method, which is a type of research that combines elements of qualitative and quantitative research approaches. The mixed explanatory sequential method is carried out through two stages: the first stage uses qualitative methods, and the second stage uses quantitative methods. Furthermore, the research factors are measured using instruments so that data in the form of numbers can be analyzed using statistical procedures [16].
The data used in this study are primary data, where data is obtained from questionnaires distributed to respondents. The sampling method used in determining respondents by purposive sampling means that every nurse who meets the criteria and is found at the time of data collection becomes a respondent. Respondents filled out a questionnaire consisting of 3 critical questions per factor. The religiosity factor is divided into 5 indicators, namely religious belief, religious practice, religious feeling, religious knowledge, and religious effect. The number of questions for the religiosity factor is 33. The local philosophy factor is only 1 indicator with 15 questions. While the nurse performance factor is divided into 5 indicators, namely assessment, nursing diagnosis, planning, implementation, and evaluation with a total of 25 questions. A total of 52 people who worked as nurses at the Mataram City General Hospital and 100 people who worked as nurses at the West Nusa Tenggara General Hospital were respondents in this study. Of the total 152 respondents, based on the sex of the respondents 110 female nurses and 42 male nurses were respondents. Meanwhile, based on education level, as many as 73 nurses with D3 level and 79 nurses with S1 level. Religiosity factor and the local philosophy factor as the independent factor and the nurse performance factor as the dependent factor.

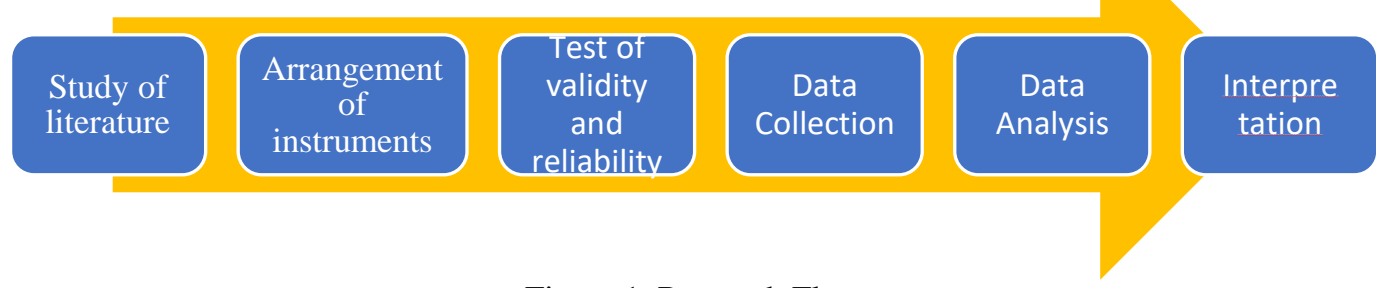

Figure 1. Research Flow

Whereas in analyzing research data, the Multiple Linear Regression method is used with the Partial Least Square (PLS) approach in finding influential factors and the magnitude of the coefficient. That is because the data in this study are in the form of an assessment of 3 factors with a Likert scale namely point 1 for strongly disagreeing, point 2 for disagreeing, point 3 for agreeing, and point 4 for strongly agree. So it is very suitable to use the PLS approach which does not require that research data patterns are assumed to follow normal distribution patterns. That is because the research data patterns certainly do not follow the normal distribution pattern.

\section{RESULTS AND DISCUSSION}

The stages of data analysis in the PLS method are outer model evaluation, inner model evaluation, and hypothesis testing. Evaluation of the outer model is the measurement of indicators against latent factors or measuring how far the indicators can explain the latent factors [17]. Outer model evaluation is done by testing the validity and reliability. Validity testing uses the value of average variance extracted
(AVE), while the reliability test uses Cronbach's alpha value. A factor is said to be convergent valid if the AVE value produced is greater than 0,5 . As for the reliability test, the value of Cronbach's alpha for each factor is greater than 0,7 [18]. The inner model evaluation is done by looking at the value of $\mathrm{R}$ Square $\left(\mathrm{R}^{2}\right)$ for each endogenous factor as the predictive power of the structural model [19].

\section{A. Results}

\section{Mataram City General Hospital}

Result of data from Mataram City General Hospital, In table 1. explain the AVE value and Cronbach's alpha value of each factor that meets the criteria. So it can be concluded that the indicators on the factors of religiosity, local philosophy, and nurse performance are said to be valid and reliable. The $\mathrm{R}^{2}$ value of the relationship between the religiosity factor and the local philosophy factor to the nurse performance factor of 0.424 . This means that $42,4 \%$ of the diversity of the Nurse Performance factor can be explained by the religiosity factor and the local philosophy factor so that the value of $\mathrm{R}^{2}$ is included in the category of a strong model. 
TABLE I. RESUlts of Test VALIDITY and Reliability Test Factors at Mataram City General Hospital

\begin{tabular}{|l|l|l|l|}
\hline Factor & AVE & Cronbach's Alpha & \multirow{2}{*}{$\mathrm{R}^{2}$} \\
\hline Religiosity & 0,939 & 0,984 & \multirow{2}{*}{0,424} \\
\hline Local Philosophy & 1 & 1 & \\
\hline Nurse Performance & 0,633 & 0,848 & \\
\hline
\end{tabular}

Figure 2 shows the magnitude of the coefficient of the effect of the relationship between religiosity and local philosophy with nurse performance. The coefficient of local philosophy factor on nurse performance factor is equal to 0,545 . While coefficient of religiosity factor on nurse performance factor is equal to 0,229 .

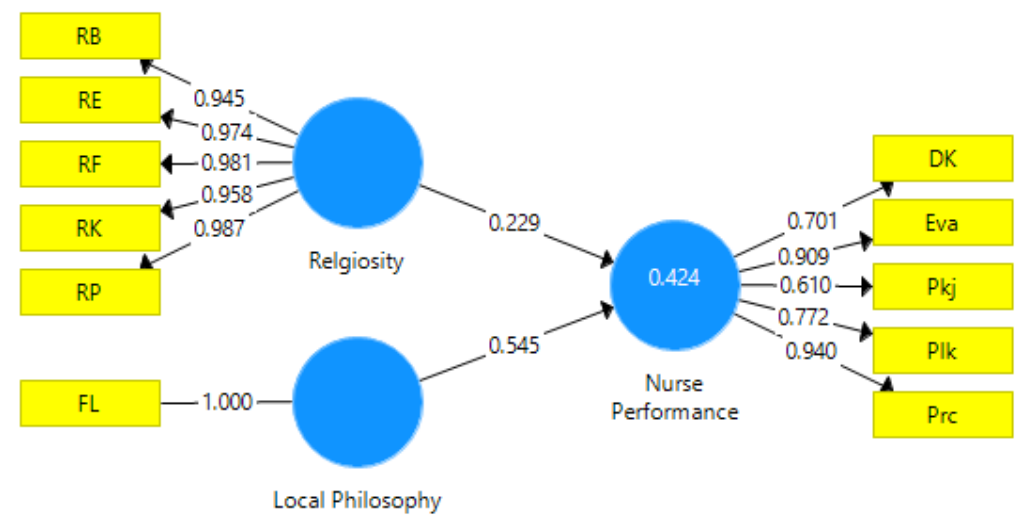

Figure 2. Religiosity and Local Philosophy Modelling Results for Nurse Performance at Mataram City General Hospital

\section{West Nusa Tenggara General Hospital}

Result of data from West Nusa Tenggara General Hospital, In table 2. explain the AVE value and Cronbach's alpha value of each factor that meets the criteria. So it can be concluded that the indicators on the factors of religiosity, local philosophy, and nurse performance are said to be valid and reliable. The $\mathrm{R}^{2}$ value of the relationship between the religiosity factor and the local philosophy factor to the nurse performance factor of 0.186 . This means that $18,6 \%$ of the diversity of the Nurse Performance factor can be explained by the religiosity factor and the local philosophy factor so that the value of $\mathrm{R}^{2}$ is included in the category of a weak model.

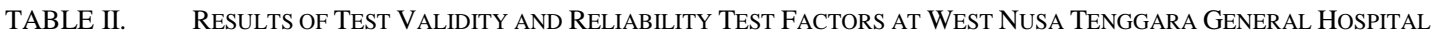

\begin{tabular}{|l|l|l|l|}
\hline Factor & AVE & Cronbach's Alpha & \multirow{2}{*}{$\mathrm{R}^{2}$} \\
\cline { 1 - 3 } Religiosity & 0,662 & 0,912 & \multirow{2}{*}{0,186} \\
\cline { 1 - 3 } Local Philosophy & 1 & 1 & \\
\hline Nurse Performance & 0,655 & 0,868 & \\
\hline
\end{tabular}

Figure 3 shows the magnitude of the coefficient of the effect of the relationship between religiosity and local philosophy with nurse performance. The coefficient of

religiosity factor on nurse performance factor is equal to 0,386 . While coefficient of local philosophy factor on nurse performance factor that is equal to 0,085 .

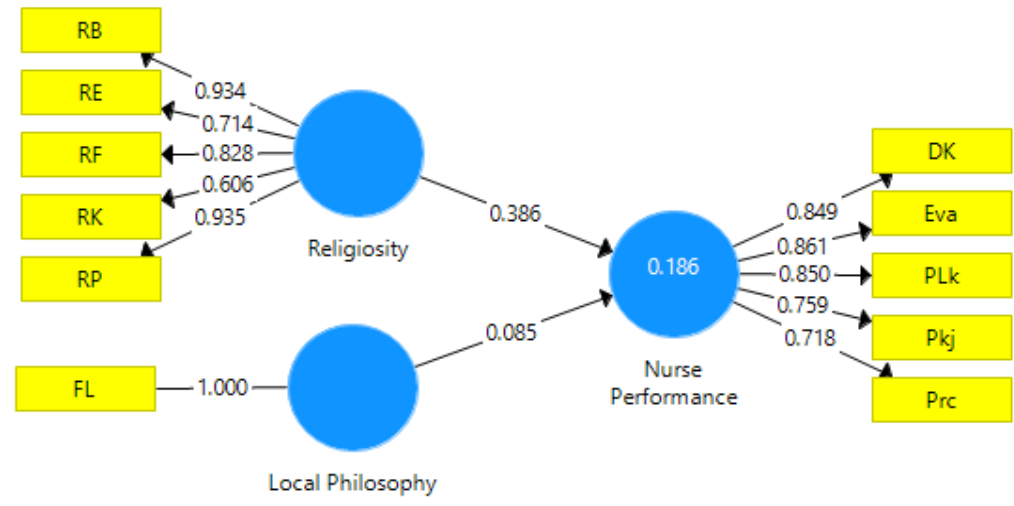

Figure 3. Religiosity and Local Philosophy Modelling Results for Nurse Performance at West Nusa Tenggara General Hospital 


\section{B. Discussion}

\section{Mataram City General Hospital}

The influence of religiosity on nurses 'performance (0.229) was very low, so it was decided that the influence of religiosity was not significant on nurses' performance. Local philosophy has a significant and large influence (0.545), this means that every increase in the value of local philosophy is 1 unit, increasing the performance value of nurses by 0.545 .

The question on the questionnaire that has the highest score with the loading factor with a value of 0.875 is question no.1.I have a cultural philosophy as a reference in action, No.3. the value of local cultural philosophy is implemented in health care, and no. 14. Speaking in a soft tone accompanied by a gesture that is not excessive when meeting and talking with patients. Meanwhile, the question with the lowest loading factor, 0.277 , is question number 10 . I shook hands when I first met my patient. The low value of question number 10 is because question number 10 is against the value of religiosity, this is because the majority of religions on the island of Lombok are Islam, in Islam, a woman is not allowed to shake hands except with a "mahram" or husband.

The significant influence of the local philosophy in the Mataram City General Hospital indicates that the cultural values contained in nurses are an important value in improving performance. Ethnic aspect is an aspect that influences nurse behavior because it is a belief that grows and develops in individuals according to the ethnic group where they are raised. Ethnicity is a determining factor for a nurse's character because it contains values or habits that are learned and embedded from childhood, thus helping to direct behavior, for example, the value of politeness, good and bad grades, grammar, and hard and soft dialects, and so on. This can indirectly affect the actions and decisions of individuals in carrying out work so that consciously or unconsciously the ethnicity attached to the individual will have an impact on social interaction and performance [20].

Indonesia is a country that has a pluralistic life consisting of various types such as Batak, Javanese, Sumatran, Bugis, Lombok, Samawa Mbojo tribes, and others so that it becomes a large tribe in the homeland. The influence of this strong local philosophy can be caused because the management of the Mataram City Regional Hospital implements the local philosophical values of the Mataram City area as part of the policy in providing health services. Besides, respondents who work are known not only to come from the city of Mataram, but also outside cities such as East Lombok, Central Lombok, West Lombok, North Lombok, Bima, Dompu, Sumbawa, Bali, and Java. The results of this study are in line with Simarmata et. al [20] that wealth, children, honor have been used as a philosophy and become the ideal of every Batak community from generation to generation, with a high cultural value of success, encouraging the Batak people to be more competitive and strive for success. This also contributed to the increase in job performance, especially in the contextual dimension of civil servant performance in Humbahas and Samosir Districts.

Research by Fridayanti [13] discusses the religiosity and spirituality of employees on employee performance. In this study, the results showed that at 5\% significance, the variable of religiosity and spirituality variable did not have a significant effect on employee performance. According to
Fridayanti, religiosity and spirituality are things that must be presented in a person, so that increasing religiosity and spirituality will not directly improve employee performance. It is estimated that other variables can bridge the increase in employee performance variables by the religiosity and spirituality variables

\section{West Nusa Tenggara General Hospital}

At West Nusa Tenggara General Hospital, the influence of local philosophy on nurse performance is very low, only 0.085 . This means that in its effect on the performance of nurses, local philosophy does not have a significant effect. While religiosity has a significant and large effect $(0.386)$, it means that every increase in the value of local philosophy is 1 unit, increasing the performance value of nurses by 0.386 .

The religiosity factor of the NTB Provincial General Hospital is strongly influenced by religious knowledge or intellectual or knowledge with a loading factor value of 0.753 , which means that the respondent gives a very positive answer to the statement in the questionnaire "I always explore religious knowledge by reading the holy book ". Meanwhile, the indicator that has a weak influence on the religiosity factor is religious belief or ideology or belief with a factor loading value of 0.047 , which means that the respondent gives a less positive response to the statement in the questionnaire "I believe in destiny given to me by God Almighty".

The results of other studies reveal that religiosity is a religious appreciation and the depth of belief which is expressed by doing daily worship, praying, and reading holy books. Religiosity has a positive and significant relationship between emotional maturity and religiosity with prosocial behavior of nurses in hospitals [2]. Building religious character in every employee/employee/nurse will certainly have a positive impact on the ability to act in providing services to patients. This has been proven through research that the quality of Islamic services has a positive and significant impact on customer satisfaction [21].

Other researchers indicate that the contribution of religious and spiritual intelligence to nurse performance is very significant. This means that nurses who have religious and spiritual intelligence have a good performance too. This shows that spiritual intelligence is important in helping workers improve their career performance [22]. Nurses who use their spiritual intelligence can motivate, enable, empower, and provide hope when they feel connected to 'God' or a higher consciousness [23]. Happy nurses are nurses who possess and apply their spiritual intelligence as they will work with satisfaction and be able to give it meaning. Therefore, nurses will take innovative care and care actions related to nursing practice, health care, health, healing, and human potential [24]

Based on this, nurses who use religious intelligence can deal with their stress and attitude problems to become highquality employees and apply good nursing techniques. Nurses who develop their spirituality can reflect it in their nursing practice, through trust, empathy relationships and it helps assure spiritual care [25]. Based on the results of other research, it shows that religiosity can color the work motivation of an individual in carrying out their activities [26]. 
West Nusa Tenggara is well known as a religious region with the majority of its adherents being Muslim. Islam teaches that if we work with trust and sincerity, we will be rewarded in this world and the hereafter. If a nurse has worked in a mandate to make her job a form of worship or a field of reward, it means that she has fulfilled her obligations and is entitled to a salary from the results of her work. The results obtained in the world are considered to be a blessing and will get a plus value, namely the reward in the hereafter.

\section{CONCLUSION}

The local philosophy factor at Mataram City General Hospital has a greater influence in improving the performance of nurses there than religiosity. Hospital management should carry out many activities that prioritize religiosity. Thus, the religiosity factor in the West Nusa Tenggara General Hospital has a greater influence than the local philosophy. This is because at the hospital the nurses who work come from various ethnic cultures. The shortage of hospitals as objects is a drawback of this study which causes a lack of data so that the results can only be generalized to 2 hospitals. There needs to be a further study by including private hospitals

\section{ACKNOWLEDGMENT}

This paper would not be finished without help, thus, we would like to thank the volunteers and all elements that we can not mention who help and support this research.

\section{REFERENCES}

[1] Departemen Kesehatan Republik Indonesia, Undang-Undang No. 44 Tahun 2009 Tentang Rumah Sakit. 2009.

[2] T. D. Haryati, "Kematangan Emosi, Religiusitas Dan Perilaku Prososial Perawat Di Rumah Sakit," Pers. J. Psikol. Indones., vol. 2 , no. 2, pp. 162-172, 2013.

[3] Kementerian Kesehatan Republik Indonesia, Peraturan Menteri Kesehatan No. 46 Tahun 2015 Tentang Akreditasi Puskesmas, Klinik Pratama, Tempat Praktik Mandiri Dokter, dan Tempat Praktik Mandiri Dokter Gigi. Indonesia, 2015.

[4] Dinas Kesehatan Provinsi NTB, "Profile Kesehatan Provinsi Nusa Tenggara Barat Tahun 2017," Mataram, 2017.

[5] L. O. Oyewobi, B. Suleiman, and A. Muhammad-Jamil, "Job Satisfaction and Job Commitment: A Study of Quantity Surveyors in Nigerian Public Service,” Int. J. Bus. Manag., vol. 7, no. 5, pp. 179_ 192, 2012, doi: 10.5539/ijbm.v7n5p179.

[6] K. Jankingthong and S. Rurkkhum, "Factors Affecting Job Performance: A Review of Literature," Silpakorn Univ. J. Soc. Sci. Humanit. Arts, vol. 12, no. 2, pp. 115-128, 2012

[7] R. Badi'ah, Mendri and R. Sutrisno, Lena, "Hubungan Motivasi Perawat Dengan Kinerja Perawat Di Ruang Rawat Inap Rumah Saki Daerah Panembahan Senopati Bantul Tahun 2008," Manaj. Pelayanan Kesehat., vol. 12, no. 02, pp. 74-82, 2009.

[8] Nurhayana and J. Sasmita, "Pengaruh Beban Kerja dan Pelatihan Melalui Motivasi Sebagai Variabel Mediasi Terhadap Perawat Ruang Rawat Inap RSUD Puri Husada DI Tembilahan," J. Tepak Manaj. Bisnis, vol. 6, no. 3, pp. 81-89, 2014
[9] R. I. Yanti and B. E. Warsito, "Hubungan Karakteristik Perawat, Motivasi, Dan Supervisi Dengan Kualitas Dokumentasi Proses Asuhan Keperawatan," J. Manaj. Keperawatan, vol. 1, no. 2, pp. 107-114, 2013.

[10] J. Saufa and T. Maryati, "Dampak Kepuasan Kerja Dalam Peningkatan Kinerja Perawat Dengan Komitmen Organisasi Sebagai Variabel Intervening ( Studi Pada Perawat Rs Pku Muhammadiyah Gamping),"JBTI J. Bisnis Teor. dan Implementasi, vol. 8, no. 2, pp. 200-213, 2017, doi: 10.18196/bti.82094.

[11] M. Muliyadi, A. Y. S. Hamid, and M. Mustikasari, "Kinerja Perawat Berdasarkan Komitmen Pada Organisasi dan Lingkungan Kerja Perawat,” J. Keperawatan Indones., vol. 13, no. 1, pp. 14-19, 2010, doi: 10.7454/jki.v13i1.225

[12] K. D. Alfisyah and M. K. Anwar, "Pengaruh Religiusitas Terhadap Kinerja Karyawan Muslim Kantor Pusat PT Perkebunan Nusantara XI,” J. Ekon. Islam, vol. 1, no. 2, pp. 99-107, 2018.

[13] F. Fridayanti, "Religiusitas, Spiritualitas Dalam Kajian Psikologi Dan Urgensi Perumusan Religiusitas Islam," Psympathic J. Ilm. Psikol., vol. 2, no. 2, pp. 199-208, 2016, doi: 10.15575/psy.v2i2.460.

[14] I. Amalia, W. Riani, and A. Julia, "The Influence of Religiosity Values on Happiness with Islamic Consuming Ethics as Moderator Variable," Procedia - Soc. Behav. Sci., vol. 219, pp. 76-83, 2016, doi: 10.1016/j.sbspro.2016.04.044.

[15] H. Sulistyo, "Peran Nilai-Nilai Religiusitas Terhadap Kinerja Karyawan Dalam Organisasi,” J. Media Ris. Bisnis Manaj., vol. 11, no. 3, pp. 252-270, 2011

[16] J. W. Cresswell, Fourth Edition Research Design Qualitative, Quantitative and Mixed Method Approaches. Sage Publications, 2018

[17] I. Ghozali, Structural Equation Modelling Metode Alternatif dengan Partial least Square. Yogyakarta: Andi Offset, 2015

[18] W. Abdillah and J. Hartono, Partial Least Square (PLS) Alternatif Structural Equation Modelling (SEM) Dalam Penelitian Bisnis. Semarang: Badan Penerbit Universitas Diponegoro, 2015.

[19] W. W. Chin, Partial Least Square to LISREL as Principal Components Analysis is to Common Factor Analysis. Technology Studies, 1995.

[20] N. I. P. Simarmata, A. L. Kadiyono, H. Agustiani, and D. Harding, "Job Performance Ditinjau Dari Iklim Organisasi dan Cultural Value Suku Batak,” J. Ilm. Psikol. Terap., vol. 5, no. 1, pp. 158-174, 2017.

[21] R. P. Putra and S. Herianingrum, "Pengaruh Kualitas Pelayanan Islami Terhadap Kepuasan dan Loyalitas Nasabah Bank BRI Syariah Surabaya,” J. Ekon. Syariah Teor. dan Terap., vol. 1, no. 9, 2014

[22] A. M. Osman-Gani, J. Hashim, and Y. Ismail, "Effects of Religiosity, Spirituality, and Personal Values on Employee Performance: A Conceptual Analysis," in 9th International Conference of the Academy of HRD (Asia Chapter), 2010, pp. 11-14.

[23] J. W. Fowler and M. L. Dell, "Stages of Faith From Infancy Through Adolescence: Reflections on Three Decades of Faith Development Theory," Handb. Spirit. Dev. Child. Adolesc., pp. 34-45, 2006.

[24] K.-P. Yang and X.-Y. Mao, "A Study of Nurses Spiritual Intelligence: A Cross-sectional Questionnaire Survey,” Int. J. Nurs. Stud., vol. 44, no. 6, 2007.

[25] M. Elkins and R. Cavendish, "Developing a Plan for Pediatric Spiritual Care," Holist. Nurs. Pract., vol. 18, no. 4, pp. 179-184, 2004

[26] F. Fauzan and I. Tyasari, "Pengaruh Religiusitas Dan Etika Kerja Islami Terhadap Motivasi Kerja," J. Ekon. Mod., vol. 8, no. 3, pp. 206-232, 2012 